\title{
A new species of planthopper from Costa Rica in the genus Oropuna from palms in lowland tropical rainforest
}

\author{
BRIAN W. BAHDER ${ }^{1,2}$, MARCO A. ZUMBADO ECHAVARRIA ${ }^{4,5}$, EDWIN A. BARRANTES BARRANTES ${ }^{4,6}$, \\ ERICKA E. HELMICK ${ }^{1,3} \&$ CHARLES R. BARTLETT ${ }^{7}$ \\ ${ }^{1}$ University of Florida, Department of Entomology and Nematology - Fort Lauderdale Research and Education Center; 3205 College \\ Ave., Davie, FL 33314-7719, USA. \\ 2 ="bbahder@ufl.edu; @ https://orcid.org/0000-0002-1118-4832 \\ ${ }^{3}$ =" ehelmick@ufl.edu; 이tps://orcid.org/0000-0002-5153-0891 \\ ${ }^{4}$ Universidad de Costa Rica-Sede San Ramón, Departamento de Ciencias Naturales, de la Iglesia el Tremedal 400 mts al Oeste car- \\ retera hacia San Pedro, San Ramón, Alajuela, Costa Rica. \\ 5!marco.zumbado@ucr.ac.cr; ”nassua75@gmail.com; (1) https://orcid.org/0000-0002-2591-7662

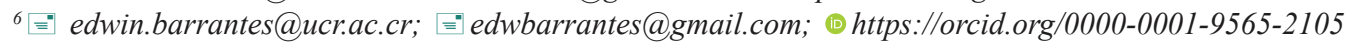 \\ ${ }^{7}$ University of Delaware, Department of Entomology and Wildlife Ecology, 250 Townsend Hall, Newark, DE 19716-2160, USA.

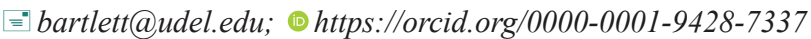

\begin{abstract}
The derbid genus Oropuna is a small taxon of Neotropical planthoppers in the tribe Cenchreini comprised of three species. Recent survey work on palms for planthoppers in Costa Rica resulted in the discovery of a fourth species, Oropuna halo sp. n. In this study the new species is described and a key to the four species is provided along with sequence data for the cyctochrome $c$ oxidase subunit I (COI) and 18S rRNA gene for the novel taxon.
\end{abstract}

Key words: planthopper, palm, phylogeny, taxonomy, Costa Rica

\section{Resumen}

El género Oropuna, perteneciente a la familia Derbidae, es un pequeño taxón de chicharritas neotropicales de la tribu Cenchreini, el cual está compuesto por tres especies. Durante una reciente investigación de campo de chicharritas en palmeras en Costa Rica, se descubrió una cuarta especie: Oropuna halo sp. n. En este documento se describe la nueva especie y se proporciona una clave para las cuatro especies, así como los datos de secuencia para la subunidad I del citocromo c oxidasa (COI) y el gen 18S rRNA para el nuevo taxón.

Palabras clave: chicharritas, palmeras, filogenia, taxonomía, Costa Rica

\section{Introduction}

The genus Oropuna Fennah is a taxon of derbid planthopper (Derbidae: Derbinae: Cenchreini) that until recently was comprised of a single species, O. minutiana (Caldwell). This species was described from Guatemala and Mexico (Chiapas) as Phaciocephalus minutianus Caldwell 1944. Two more species were recently added to the genus by Bahder et al. (2021a) with Oropuna orba (Stål) (from Brazil), transferred from Phaciocephalus Kirkaldy, and Oropuna fusca (Metcalf) (From Panama) transferred from Herpis Stål. Members of Oropuna are 'cixiid-like' derbids with tectiform wings and a pronotal paradiscal regions forming foliate, cup-like fossae behind the antennae. Oropuna is moderately robust among Cenchreini, approximately 3-6 mm (with wings), with broad frons (weakly concave) that lacks the median carina found in Herpis.

The genus Oropuna was established by Fennah (1952: 136-137) based on the shape of the vertex (“...distinctly 
broader than long in middle, apically transverse; lateral margins broadly explanate and beset with sensory pits..."), the frons ("...frons only slightly more than twice as long as broad; disc not depressed, ecarinate, lateral margins not elevated...") and the shape of the medioventral process ("...large subquadrate or trapezoidal medioventral process..."). In the keys to the Cenchreini by both Fennah (1952) and O'Brien (1982) these features were used to contrast Oropuna with those of Herpis Stål. The genus Herpis is contrasted with Oropuna in (Fennah 1952: 128) as having a "vertex as long as broad or longer than broad"; frons medially carinate and the "medioventral process [of the pygofer] triangular". This last feature may be misleading as it appears that Oropuna has a notably broader medioventral process of the pygofer than Herpis (e.g., Caldwell 1944, plate 1 fig. 2C).

At present, there is no molecular data available for Oropuna, which makes it more difficult to assess its relationship among the Cenchreini from the New World. Superficially, Oropuna most closely resembles Herpis based on head morphology, being the only two genera with a 'broad' frons.

Recent survey efforts in the Neotropics have yielded many novel taxa within the Derbidae and Cixiidae closely associated with palms. As part of this survey, an expedition in June of 2019 resulted in the collection of what was identified in the field as a derbid planthopper from a variety of palm seedlings at La Selva Biological Station in Costa Rica, and subsequently determined to belong to Oropuna and represent a new species. Herein we describe the novel taxon, provide molecular sequence data for the COI and 18S loci, and present some discussion of genus-level diagnostic features of Oropuna relative to other New World Cenchreini.

\section{Materials and methods}

Locality and Specimen Collection. Individuals of the novel taxon were collected by sweep netting trailside palms, aspirated and were immediately transferred to $95 \%$ ethanol. Specimens were collected (permit no. SINAC-ACToGASPPNI-016-2018) at La Selva Biological Station, Heredia province, Costa Rica (10.431269, -84.005961), and exported under permit number DGVS-256-2018 to the U.S.A. under permit number P526-170201-001. All specimens collected were measured, photographed and dissected using a Leica M205 C stereoscope. Images of specimens and all features photographed were generated using the LAS Core Software v4.12. Voucher specimens, including primary types, are stored at the University of Florida-Fort Lauderdale Research and Education Center (FLREC) in Davie, FL, U.S.A and the Florida State Collection of Arthropods (FSCA) in Gainesville, FL, U.S.A.

Morphological Terminology and Identification. Morphological terminology generally follows that of Bartlett et al. (2014), except forewing venation following Bourgoin et al. (2015) and with male terminalia nomenclature modified after Bourgoin (1988) and Bourgoin \& Huang (1990).

Dissections and DNA Extraction. The terminalia that were dissected also served as the source of tissue for DNA extraction. The terminal end of the abdomens was removed and placed directly into a solution of tissue lysis buffer (buffer ATL) and proteinase K (180 $\mu 1$ ATL and $20 \mu 1$ proteinase K) from the DNeasy ${ }^{\circledR}$ Blood and Tissue Kit (Qiagen). The abdomen was left to lyse for 24 hours at $56^{\circ} \mathrm{C}$. Following lysis, eluate was transferred to a new 1.5 $\mathrm{ml}$ microcentrifuge tube and DNA extraction proceeded as per the manufacturer's instructions. The terminalia were then immersed in $200 \mu \mathrm{l}$ of buffer ATL and $200 \mu \mathrm{l}$ of buffer AL from the same kit and placed at $95^{\circ} \mathrm{C}$ for 24 hours to remove fat, wax, and residual tissue.

PCR Parameters, Sequence Data, and Analysis. To obtain COI sequence data, DNA template from specimens was amplified using the primers TY-J-1460 (5'- TACAATTTATCGCCTAAACTTCAGCC -3') (Simon et al. 1994) and HCO2198 (5'-TCAGGGTGACCAAAAAAATCA-3') (Folmer et al. 1994). To obtain 18S sequence data, the primers developed by Bahder et al. (2019) were used and are as follows; forward primer 18SF (5'-ACTGTCGATGGTAGGTTCTG-3'), reverse primer 18SR (5'-GTCCGAAGACCTCACTAAA-3'). PCR reactions contained 5x GoTaq Flexi Buffer, $25 \mathrm{mM} \mathrm{MgCl}{ }_{2}, 10 \mathrm{mM}$ dNTP's, $10 \mathrm{mM}$ of each primer, 10\% PVP-40, and 2.5U GoTaq Flexi DNA Polymerase, $2 \mu \mathrm{l}$ DNA template, and sterile $\mathrm{dH}_{2} 0$ to a final volume of $25 \mu \mathrm{L}$. Thermal cycling conditions for COI were as follows: 2 min initial denaturation at $95^{\circ} \mathrm{C}$, followed by 35 cycles of $30 \mathrm{sec}$ denaturation at $95^{\circ} \mathrm{C}, 30$ sec annealing at $40^{\circ} \mathrm{C}, 1 \mathrm{~min} 30 \mathrm{sec}$ extension at $72^{\circ} \mathrm{C}$, followed by a $5 \mathrm{~min}$ extension at $72^{\circ} \mathrm{C}$. Thermal cycling conditions for $18 \mathrm{~S}$ were as follows: 2 min initial denaturation at $95^{\circ} \mathrm{C}$, followed by 35 cycles of $30 \mathrm{sec}$ denaturation at $95^{\circ} \mathrm{C}, 30 \mathrm{sec}$ annealing at $55^{\circ} \mathrm{C}, 2 \mathrm{~min}$ extension at $72^{\circ} \mathrm{C}$, followed by a $5 \mathrm{~min}$ extension at $72^{\circ} \mathrm{C}$. PCR products of the appropriate size were purified using the Exo-SAP-IT ${ }^{\mathrm{TM}}$ PCR Product Cleanup Reagent (ThermoFisher Scientific, Waltham, Massachusetts, USA). Purified PCR product was quantified using a NanoDropLite spectrophotometer 
(ThermoFisher Scientific, Waltham, Massachusetts, USA) and sequenced using the SeqStudio Genetic Analyzer (ThermoFisher). Contiguous files were assembled using DNA Baser (Version 4.36) (Heracle BioSoft SRL, Pitesti, Romania), aligned using Clustal $\mathrm{W}$ as part of the package MEGA7 (Kumar et al. 2016). A matrix of pairwise differences using number of differences among COI and $18 \mathrm{~S}$ was calculated with MEGA7 (Kumar et al. 2016). The bootstrap method was used for variance estimation at 1,000 replicates and using the $\mathrm{p}$-distance model. A Maximum Likelihood tree was generated using the Bootstrap method at 1,000 replicates based on the Tamura-Nei model for concatenated COI and $18 \mathrm{~S}$ data to yield a consensus tree.

Taxon sampling. For both the COI and $18 \mathrm{~S}$ loci, DNA sequence data was used from eight species of Omolicna Fennah, four species of Agoo Bahder \& Bartlett, two species of Tico Bahder \& Bartlett, Anchimothon dubia (Caldwell), Cenchrea dorsalis Westwood, Herpis soros Bahder \& Bartlett and Neocenchrea heidemanni (Ball) to generate a consensus tree (Table 1).

For morphological characterization of the genus, we obtained photos of the type specimen of Oropuna minutianus Caldwell (from the Smithsonian Institution, Washington, DC; USNM), the type specimen of Oropuna orba Stål (Swedish Natural History Museum, Stockholm Sweden, NHRS), and the type specimen of Syntames fuscus Metcalf (Harvard Museum of Comparative Zoology, Cambridge, MA; MCZC).

TABLE 1. Taxa used for constructing phylogeny based on the COI and $18 \mathrm{~S}$ genes and performing pairwise comparisons.

\begin{tabular}{|c|c|c|}
\hline \multirow[b]{2}{*}{ Species } & \multicolumn{2}{|c|}{ GenBank Accession No. } \\
\hline & COI & $18 \mathrm{~S}$ \\
\hline Agoo beani & MT413388 & MT415403 \\
\hline Agoo dahliana & MN496467 & MH472754 \\
\hline Agoo luzdenia & МТ085818 & MN999709 \\
\hline Agoo xavieri & MK443068 & MK443073 \\
\hline Anchimothon dubia & MN496470 & MN474755 \\
\hline Anotia firebugia & MT084365 & MT945942 \\
\hline Cenchrea dorsalis & MT413387 & MN472756 \\
\hline Herpis soros & MT085817 & MT415405 \\
\hline Neocenchrea heidemanni & MN496473 & MT415406 \\
\hline Omolicna brunnea & MK443070 & MK443071 \\
\hline Omolicna cubana & MT413386 & MT415404 \\
\hline Omolicna joi & KF472312 & MN472753 \\
\hline Omolicna latens & MN496472 & MN472757 \\
\hline Omolicna mariajoseae & MT422534 & MT424915 \\
\hline Omolicna puertana & MN496468 & MN472751 \\
\hline Omolicna tarco & MT422533 & MT424914 \\
\hline Omolicna triata & MK443069 & MK443072 \\
\hline Tico emmettcarri & MT085816 & MT526036 \\
\hline Tico pseudosoroius & МТ997938 & MT526037 \\
\hline
\end{tabular}

\section{Systematics}

Family Derbidae Spinola 1839

Subfamily Derbinae Spinola 1839

Tribe Cenchreini Muir 1913 


\section{Genus Oropuna Fennah 1952}

Type species: Oropuna minutianus Caldwell, 1944: 102.

Amended Diagnosis. Relatively large and robust among Cenchreini, measuring approximately $3.8-5.5 \mathrm{~mm}$ in length, including wings. Wings tectiform in repose, distinctly exceeding abdomen. Vertex broad, nearly trapezoidal (anterior margin transverse to weakly convex, posterior margin concave), nearly $2 \mathrm{x}$ as broad at posterior margin as long at midline; lateral margins keeled ("explanate", Fennah 1952: 136), converging anteriorly (slightly broader at apex); transverse carinae at fastigium faintly indicated. Pits present on lateral margins of vertex and frons, varying in size and distinctness, in $2+$ rows. Frons broad, elongate, weakly concave, lateral margins keeled, slightly diverging to widest point approaching frontoclypeal suture; medium carina of frons absent, frontoclypeal margin straight. Clypeus elongate triangular, median carina evident, in lateral view in approximately same plane as frons. Genae without subantennal process. Antennae short, pedicle spheroid, about as long as wide.

Pronotum narrow, declinate (posterior margin raised), anterior margin convex, posteriorly broadly concave or $\mathrm{v}$-shaped, broadening laterally; paranotal region foliate, forming large foveae posterior to the antennae (a tribal feature). Mesonotum tricarinate, carinae nearly reaching posterior margin, scutellum faintly discontinuous with scutum (not separated by groove). Lateral teeth absent on tibiae. In clavus of forewing, combined vein Pcu+A1 fusing with $\mathrm{CuP}$, with the composite vein reaching wing margin near icu crossvein; $\mathrm{C} 5$ cell (formed by forked $\mathrm{CuA}$ ) closed by crossvein (not anastomosing CuA, viz. Emeljanov 1996: 74); RP usually 5-branched (4 in $O$. orba).

Terminalia mostly bilaterally symmetrical, except aedeagus asymmetrical. Pygofer in lateral view narrow, strap-like, arched (caudal margin convex, anterior margin concave), ventral margin broadly expanded; in ventral view, medioventral process very broad, subquadrate, apex truncate to broadly triangular. Gonostyli elongate, narrow (relative to Herpis), distally enlarged with a twisted appearance, bearing a thumb-like process on dorsal surface and in ventral view two large medially directed processes. Aedeagus symmetrical or asymmetrical, shaft bearing dorsolateral keels and apical or subapical processes, endosoma complex with a variety of sclerotized processes. Anal tube length highly variable.

Distribution. Mexico (Chiapas); Guatemala; Costa Rica; Southeast Brazil (Rio de Janiero); Bolivia (Cochabamba).

Etymology. Fennah (1952) did not specify an origin of the genus name 'Oropuna', and the derivation of the term does not appear obvious. The name may have come from the Oropuna River in Trinidad (or the town of Oropune) but there is no connection with that place. Possibly the name is derived from the Greek term 'oros', or the Latin term 'orias', meaning mountain or hill, plus a form of the Latin verb 'punio' (punish). Oropuna is treated as masculine.

Remarks. This genus appears to be most similar to Herpis in general appearance, especially the broad frons. In Herpis the frons appears to be flat, parallel sided and bearing a median carina, in Oropuna the frons is weakly convex, lacking the median carina and the lateral margins diverging ventrally. The vertex in both genera are trapezoidal, but in Oropuna it is about 2x as wide at base as long at midline, whereas in Herpis the vertex is longer in midline. In male genitalia, the medioventral process is large, broad and subquadrate (unique among New World Cenchreini), whereas in Herpis it is subconical, usually taller than broad. Among species examined so far, Herpis has broad, spatulate gonostyli with a single medially directed process in ventral view; whereas Oropuna is narrow, with two medial processes in ventral view. In the forewing, Oropuna has 4-5 branches of the RP, and Herpis apparently has 6-branches, at least among the species examined, the species that we have examined so far in Herpis are all pallid in coloration relative to Oropuna.

The only genus, other than Herpis, whose head structure may approach that of Oropuna are some of the members of Omolicna Fennah. However, in this genus, the frons is more distinctly convex (and enlarged near the frontoclypeal border), and the medioventral process of the pygofer is not nearly as broad.

\section{Key to species of Oropuna}

1. Body uniformly brown (Fig. 7), wings evenly suffused with fuscus (except near apices of Sc and RA along costal margin); most veins near wing apex reddish (up to crossvein or fork); Brazil $\ldots \ldots \ldots \ldots \ldots \ldots \ldots \ldots \ldots \ldots \ldots \ldots \ldots \ldots$

1.' Body paler, and/or wing not evenly suffused with fuscus (Fig. 1); apical wing veins not reddish, only wing margin and imme- 


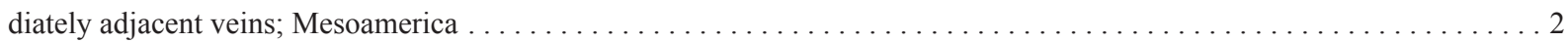

2. Medioventral lobe of male pygofer (ventral view) distinctly longer than wide, elongate-ovoid; gonostyli, in ventral view, with medial margin smooth, lacking medially directed lobes (Metcalf 1938, plate 20); Panama ................ O. fusca

2.' Medioventral lobe of male broad and about as wide as tall (ventral view), roughly quadrate; gonostyli in ventral view with 2

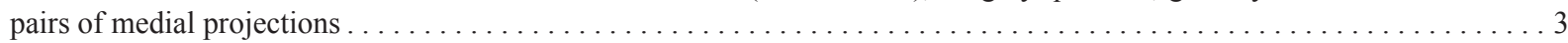

3. Apex of the medioventral lobe of male pygofer with broadly acute apex (Fig. 4B); anal tube subequal in length to gonostyli,

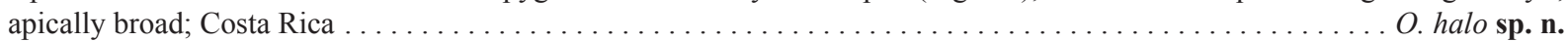

3. Apex of the medioventral lobe of male pygofer truncate; anal tube much shorter than gonostyli (Caldwell 1944, plate I, figs 2B,

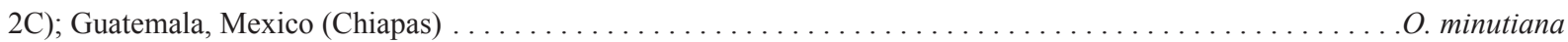

\section{Oropuna halo sp. n.}

(Figures 1-6)

Type locality. Costa Rica, Heredia, La Selva Biological Station.

Diagnosis. General body color brown, abdomen darker, wings infuscate, veins paler, marginal vein on wing apex reddish. Medioventral process of pygofer broad and spade-shaped, aedeagus bilaterally asymmetrical with complex arrangement of processes; anal tube elongate, in lateral view narrow basally with ventro-distal margin expanded into large truncate projections.

Description. Color. General body color yellow-brown, head and prothorax testaceous, clypeus light brown, mesonotum darker brown in anterior $2 / 3$, with posterior $1 / 3$ lighter brown, with paler carinae, give the appearance of a median vitta; abdominal tergites and sternites dark brown (Fig. 1A \& 1B). Forewing fuscous, veins white, dark patches in cells along leading margin, in the areola postica near apex of clavus, and between the Pcu and A1 veins in the clavus.

Structure. Head. Head in lateral view with fastigium rounded (Fig. 2C) flattened on face, receding to frontoclypeal suture and clypeus. Vertex broad, trapezoidal (expanded slightly distally), medially concave, wider at base than long at midline (ratio 1.95:1 Fig. 2B), anterior margin nearly transverse (weakly convex), lateral margins sinuate, weakly foliate bearing $2+$ rows of irregularly sized (mostly large) and arranged pits; posterior margin concave. In frontal view, vertex appearing weakly medially produced, transverse carina at fastigium obscure. Frons wide, lateral margins straight and slightly diverging ventrad, widest near frontoclypeal suture (Fig. 2A), irregularly sized wax-producing pits on vertex (Fig. 2B) and frons on lateral margins arranged in 2+ irregular rows; disc of frons weakly convex, lacking median carina, bearing minute scattered pits (Fig. 2A). Frontoclypeal suture straight, clypeus elongate triangular (lateral margins straight and uniformly converging ventrad), median carina present. Antennae short, scape very short, pedicle spheroid, about as tall as wide, greatly overtopped by foliation of pronotal paradiscal region. Lateral ocelli absent (indicated by small whitish marking). Rostrum exceeding hind coxae, apical segment over $2 \mathrm{x}$ as long as wind.

Thorax. Pronotum, in dorsal view, very short at midline (less than half length vertex at midline), broadened laterally, anterior margin convexly rounded, posterior margin deeply concave; median carina evident, laterally, paradiscal region strongly foliate forming semicircular fossae, partially surrounding antennae; lateral margins in frontal view rounded (Fig. 2A). Mesonotum rhomboid, slightly wider than long, tricarinate, lateral carinae diffuse, arching mesad at midpoint, diverging posteriorly, not reaching posterior margin; median carina evident anteriorly, obsolete posteriorly (Fig. 2B); scutellum contiguous with scutum.

Forewing with large tubercles along Sc+R and Pcu (Fig. 3), claval apex near midlength (Pcu joined with A1 just before composite vein joins with $\mathrm{CuP}$ - clavus open — composite vein reaching wing margin at icu crossvein); fork $\mathrm{Sc}+\mathrm{PA}$ from RP and fork of $\mathrm{CuA}$ both at basal third of wing (prior to $\mathrm{Pcu}+\mathrm{A} 1$ fusion); $\mathrm{C} 5$ cell closed by icua crossvein (CuA not anastomosing to form closed 'procubital cell' sensu Emeljanov 1996; vein branching pattern RA two-branched, RP two-branched, MP five-branched, CuA two-branched. Tibiae of legs lacking lateral teeth, spinulation of hindleg 6-7-8.

Terminalia. Pygofer in lateral view narrow, strap-like, narrowed dorsally, broadly expanded expanding ventrally margins irregularly sinuate, concave on anterior margin and convex posteriorly (Fig. 4A); in ventral view, medioventral process large, at base, almost as wide as pygofer, spade-shaped, lateral margins converging to approximately midpoint, angled to near parallel-sided then abruptly converging to broadly pointed apex (Fig. 4B). Gonostyli in lateral view very irregularly sinuate on dorsal and ventral margin, with large, curved expansion on dorsal margin past midpoint subtended by pale expansion bearing small, sclerotized curved spine directed caudad (Fig. 
4A); distal expansion comprised of curled gonostylus margin, distally expanding to apex (Fig. 4A); in ventral view, medial margin of gonostyli with two medial projections each, proximal projection in basal third (near level of apex of medioventral lobe of pygofer), ovoid and rounded at apex (directed mediocaudad), distal pair at distal 2/3 $3^{\text {rd }}$ level, triangular and sharply pointed bearing ventral sclerotized ridge (Fig. 4B); gonostyli apices rounded, caudomedially directed. Aedeagus bilaterally asymmetrical (Fig. 5), shaft nearly straight (upturned basally), bearing complex series of sclerotized ridges and a pair of apical retrorse processes, left process (Fig. 6, A2) about 2/3 twice length of right process (A1), A1 curved distad, A2 curved dorsolaterally. Endosoma large, retrorse and complex, bearing six pairs of processes (E1-E12), first pair arising near shaft apex, resting lateral of A1 \& A2 (E1 \& E2), angled anteriorly, slender, curved slight ventrodistad, E1 exceeding E2, E1 exceeding A2 (but not A1), E2 just shorter than A2; second pair (E3 \& E4) arising near base of E1 \& E2, situated lateral of aedeagal shaft, slender and elongate (about 2/3 length of shaft), apex of E3 slightly curved dorsad, apex of E4 curved ventrad; third pair (E5 \& E6) forming apices of broad, flat weakly sclerotized central strap-like region, E5 shorter and curved slightly dorsad, E6 longer, curved ventrad and twisted; fourth pair (E7 \& E8) situated lateral aspect of central strap-like region, arising lateroventrally (Figs. 6A, B), E8 shorter and arising just proximad of E7, both curved dorsolaterally; the fifth pair (E9 \& E10) arising ventrad of large central region, long, strongly sclerotized, intertwined, E9 strongly curved dorsad (just exceeding apex of endosoma), E10 strongly curved lateroventrad; sixth pair of processes (E11 \& E12) arising on ventral margin of aedeagus, small, robust, curved dorsad, not extending beyond apex of aedeagus. Anal tube in lateral view elongate (subequal to gonostyli in length), narrow basally, distally expanded, irregularly sinuate on ventral margin (Fig. 4A); in dorsal view lateral margins of proximal portion sinuate, roughly parallel-sided, distally expanded just before anal column (paraproct) forming pair of weakly asymmetrical lateral lobes (Fig. 4C).

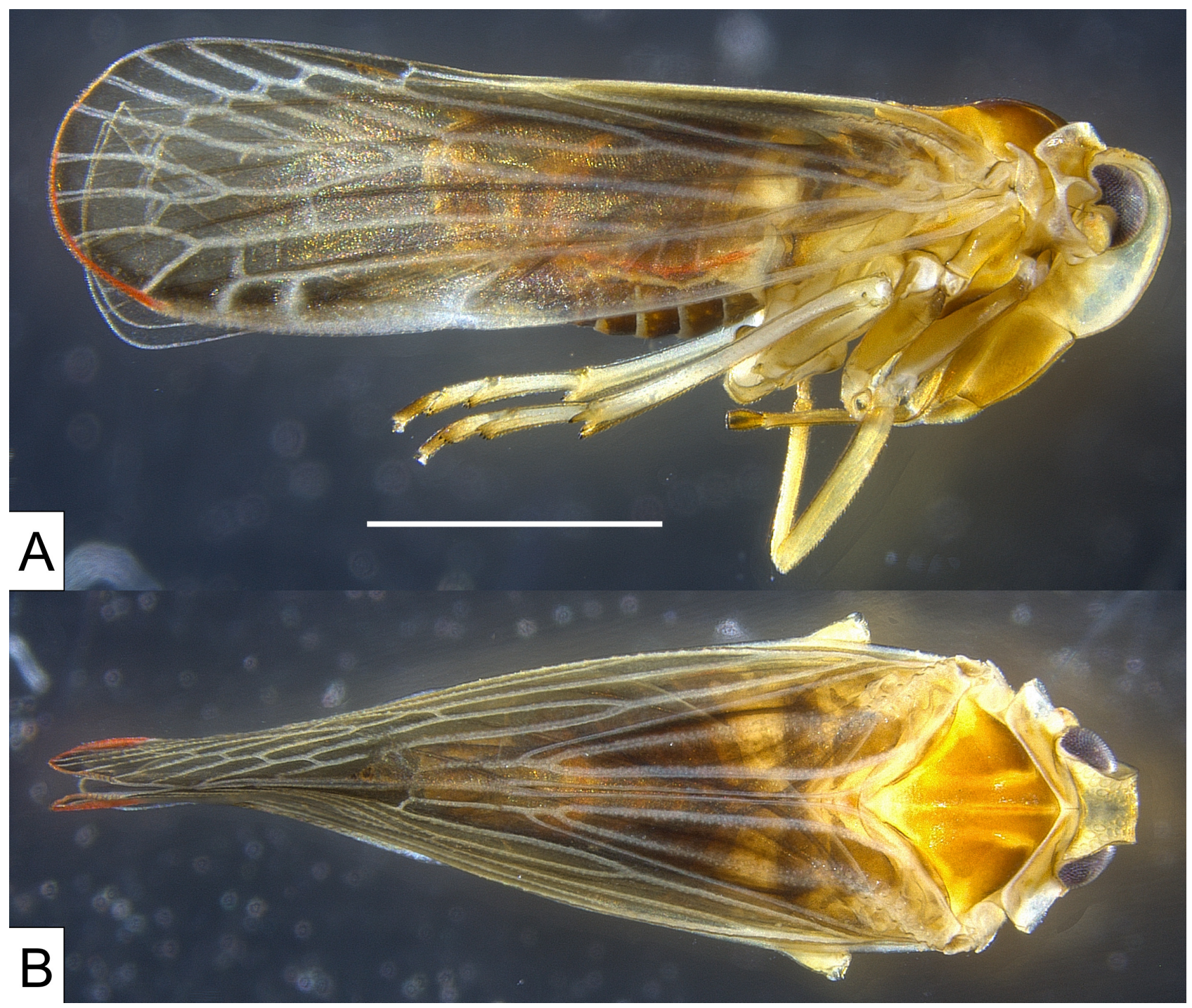

FIGURE 1. Adult male habitus of Oropuna halo sp. n.; (A) lateral view and (B) dorsal view, scale $=1 \mathrm{~mm}$. 


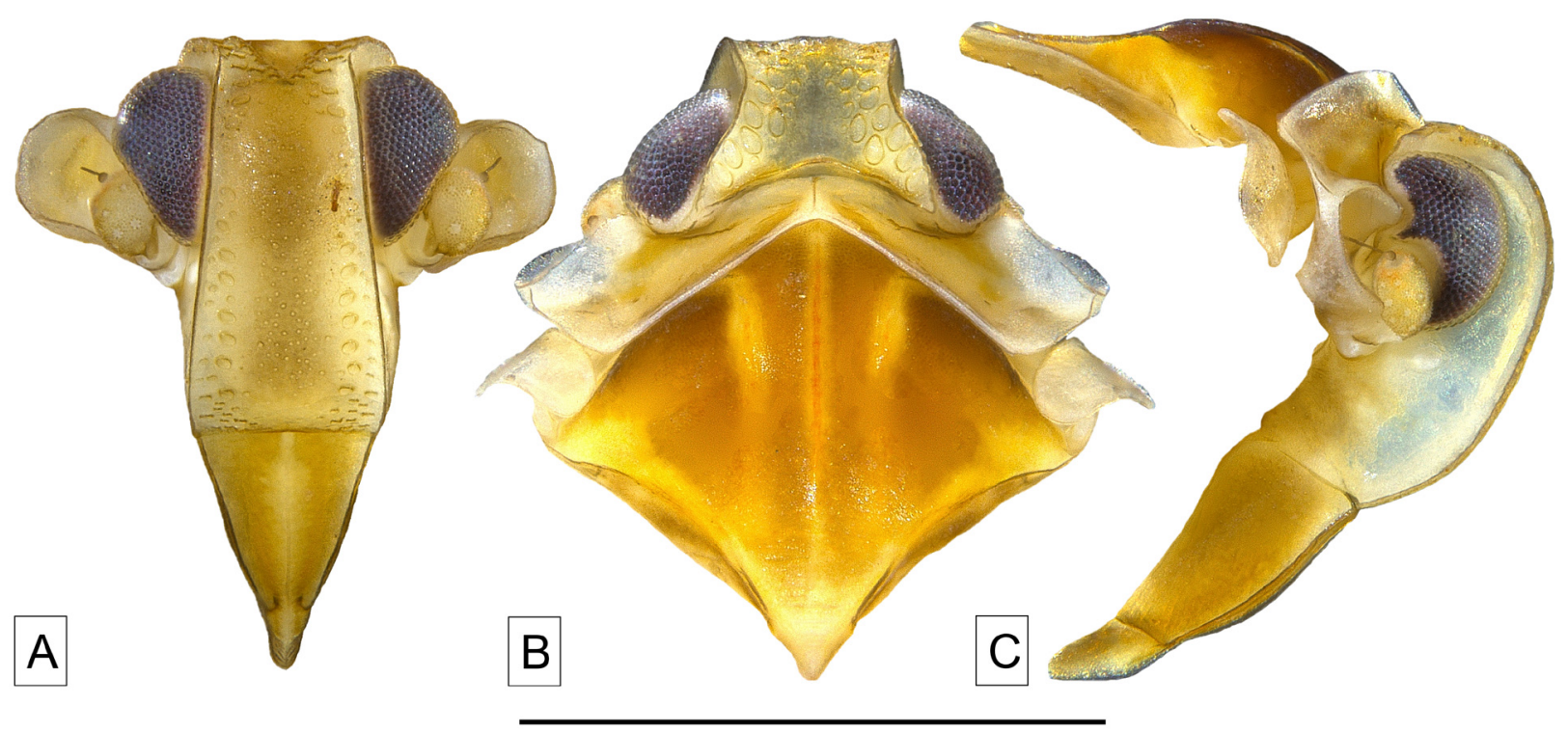

FIGURE 2. Adult Oropuna halo sp. n.; (A) head and pronotum frontal view, (B) head, pronotum, and mesonotum dorsal view, and $(\mathrm{C})$ head, pronotum, and mesonotum lateral view; scale $=1 \mathrm{~mm}$.

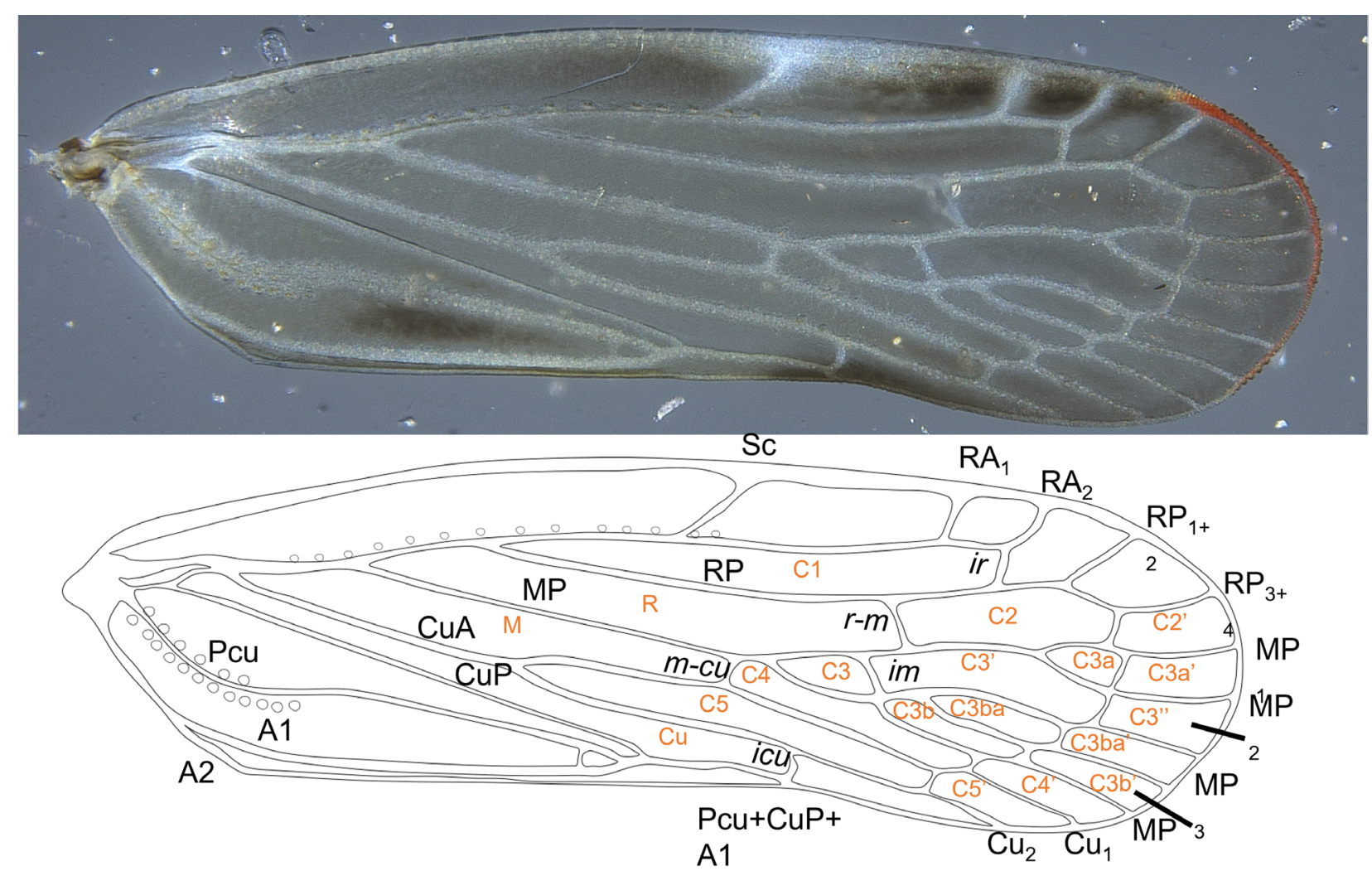

FIGURE 3. Forewing venation of Oropuna halo sp. n.; black = vein, italics $=$ crossvein, orange $=$ cell.

Plant associations. Palms (Arecaceae). Collected by sweeping palm seedlings in understory of primary rainforest (approximately $70 \mathrm{~m}$ above sea level).

Distribution. Costa Rica (Heredia Province)

Etymology. The specific name is given in reference to the video game 'Halo' due to the resemblance of the aedeagus to the 'needler' from the game.

Material examined. Holotype male, "Costa Rica, Heredia Pr. / La Selva Biological Station / 21.VI.2019 / Coll.: B.W. Bahder, sweeping palms / Holotype Oropuna halo ${ }^{\text {त” }}$ (FLREC). Paratypes: 2 males, 3 females, same data as holotype (FSCA). 
TABLE 2. Biometric data for Oropuna halo sp. n.

\begin{tabular}{lcccc}
\hline & \multicolumn{2}{c}{ Male } & \multicolumn{2}{c}{ Female } \\
\cline { 2 - 5 } Character & Range & Average \pm SE & Range & Average \pm SE \\
\hline Body length, with wings & $3.80-3.84$ & $3.83 \pm 0.01$ & $3.94-3.95$ & $3.94 \pm 0.01$ \\
Body length, no wings & $2.56-2.59$ & $2.58 \pm 0.02$ & $2.7-2.72$ & $2.71 \pm 0.01$ \\
Forewing length & $3.26-3.28$ & $3.27 \pm 0.01$ & $3.41-3.50$ & $3.43 \pm 0.04$ \\
Vertex length & $0.19-0.19$ & $0.19 \pm 0.00$ & $0.21-0.21$ & $0.21 \pm 0.00$ \\
Vertex width, basal margin & $0.37-0.37$ & $0.37 \pm 0.00$ & $0.42-0.42$ & $0.42 \pm 0.00$ \\
Vertex width, distal margin & $0.21-0.21$ & $0.21 \pm 0.00$ & $0.24-0.25$ & $0.24 \pm 0.01$ \\
Pronotum length, midline & $0.09-0.09$ & $0.09 \pm 0.00$ & $0.12-0.12$ & $0.12 \pm 0.00$ \\
Mesonotum length, midline & $0.70-0.70$ & $0.70 \pm 0.00$ & $0.90-0.90$ & $0.90 \pm 0.00$ \\
Mesonotum width & $0.81-0.81$ & $0.81 \pm 0.00$ & $0.91-0.91$ & $0.91 \pm 0.00$ \\
Frons width, dorsal margin & $0.24-0.24$ & $0.24 \pm 0.00$ & $0.26-0.26$ & $0.26 \pm 0.00$ \\
Frons width, clypeal suture & $0.29-0.29$ & $0.29 \pm 0.00$ & $0.31-0.31$ & $0.31 \pm 0.00$ \\
Frons width, widest & $0.32-0.32$ & $0.32 \pm 0.00$ & $0.34-0.34$ & $0.34 \pm 0.00$ \\
Frons width, narrowest & $0.24-0.24$ & $0.24 \pm 0.00$ & $0.25-0.25$ & $0.25 \pm 0.00$ \\
Frons length, midline & $0.57-0.57$ & $0.57 \pm 0.00$ & $0.59-0.59$ & $0.59 \pm 0.00$ \\
Clypeus length & $0.34-0.34$ & $0.34 \pm 0.00$ & $0.36-0.36$ & $0.36 \pm 0.00$ \\
\hline
\end{tabular}

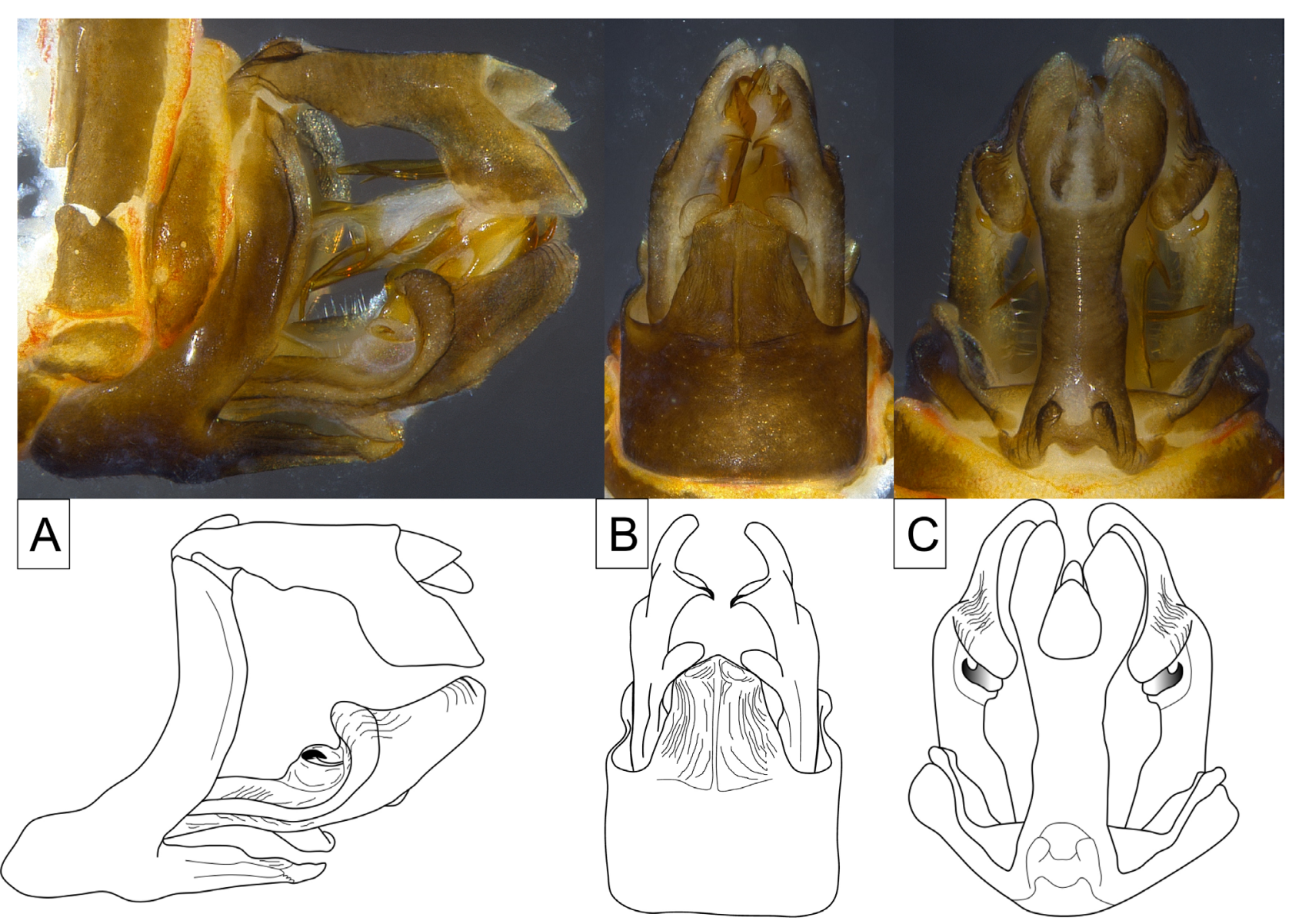

FIGURE 4. Male Oropuna halo sp. n. terminalia; (A) lateral view, (B) ventral view, and (C) dorsal view.

Other species examined. Oropuna orba (Fig. 8)—“ Brasil // Typus // NHRS-GULI / 000041829”. Oropuna minutiana (Fig. 9) _ “M.F.892 / B. Esperanza / XII-14-25Guat. // Phaciocephalus / Holotype / minutianus // JSCaldwell / Collection / 1959”. Oropuna fusca (Fig. 10)_“Canal Zone: / Barro, / Colorado. / 19-VI 1924. / N. Banks. // M. C. Z. / Type / 22245 // Syntames / fusca / Det. Z.P.M. Met. // MCZ-ENT / 00022245”. 


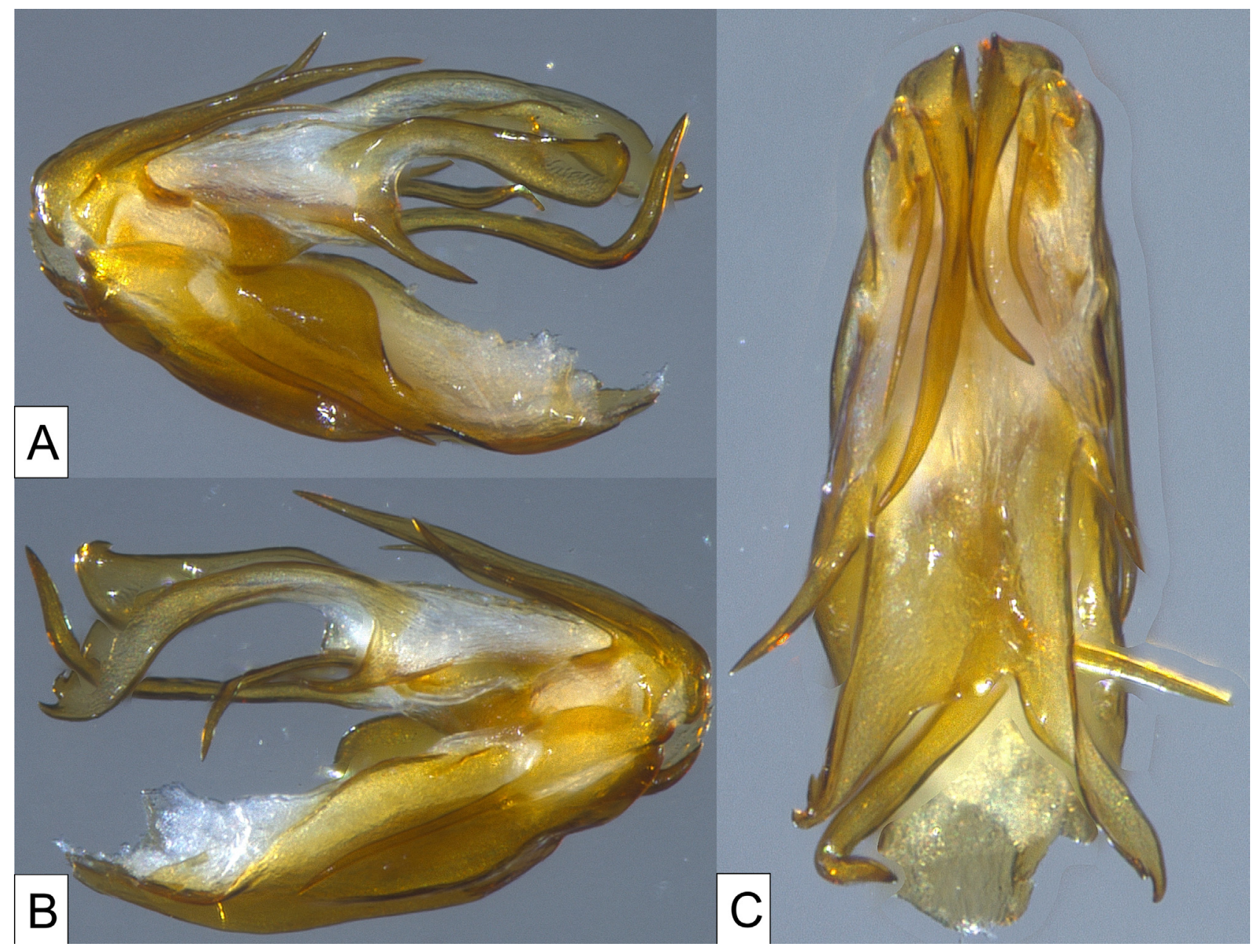

FIGURE 5. Aedeagus of Oropuna halo sp. n.; (A) right lateral view, (B) left lateral view, and (C) dorsal view.

Sequence data. For the COI locus, a 636 bp product was generated (GenBank Accession No. MZ836006) and for the 18S locus, a 1,363 bp product was generated (GenBank Accession No. MZ828126). Based on the phylogenetic analysis for COI, 18S, and the consensus tree, Oropuna halo sp. n. resolves closest to the genus Herpis (Fig. 7). The level of variability observed between $O$. halo sp. n. and Herpis (4.4\%) is consistent with genus-level variability for $18 \mathrm{~S}$ based on the pairwise comparison (Table 3 ). For the taxa analyzed, the average variability among genera was $5.9 \%( \pm 3.6)$. The average variability among species in the same genus is less than $1 \%$ for $18 \mathrm{~S}$ (Table 3 ).

Remarks. Oropuna halo sp. n. can be diagnosed from $O$. minutiana most readily by the terminalia, especially that medioventral process of $O$. halo is broad, with a broadly triangular apex (broad and truncate in $O$. minutiana, elongately oval in $O$. fusca, males not known for $O$. orba), the anal tube is elongate and distally broad (short in $O$. minutiana, elongate but not as broad in $O$. fusca). The aedeagus in $O$. halo sp. n. is bilaterally asymmetrical and has a complex assortment of processes (fewer in O. minutiana, not yet examined in other species). For Oropuna minutiana, both Caldwell 1944 and Fennah 1952 both state that the aedeagus is symmetrical. O. halo sp. n. also has a reddish margin at the apex of the wing (absent in O. minutiana).

The terminalia of Oropuna orba are not described (and the type specimen is a female), however, that species is more deeply colored - with the wings almost entirely deep fuscus - with the distal wing margin and some veins reddish.

While material for the other species of Oropuna were not available for sequence analysis, the morphological characters described by Caldwell (1944) and Fennah (1952) support the placement of Oropuna halo sp. n. within Oropuna; based on the general form of the medioventral process of the pygofer, parameres, and shape of the frons. The size of the anal segment which in O. minutiana it is documented as being exceptionally small whereas Oropuna halo sp. n. has a relatively large anal segment, indicating that the size of the anal segment is not a useful genus level feature as stated by Fennah (1952). Furthermore, sequence analysis places the novel taxon sister to Herpis and not within any other cenchreine genus available for analysis. 
The genus Oropuna appears closest to Herpis based on general morphology and based on DNA sequence analyses. The distinguishing characters for Oropuna (relative to Herpis) are lacking the median carina on the frons that is present in Herpis and the presence of two pairs of projections on the inner margins of the parameres in ventral view, whereas Herpis only has one pair.

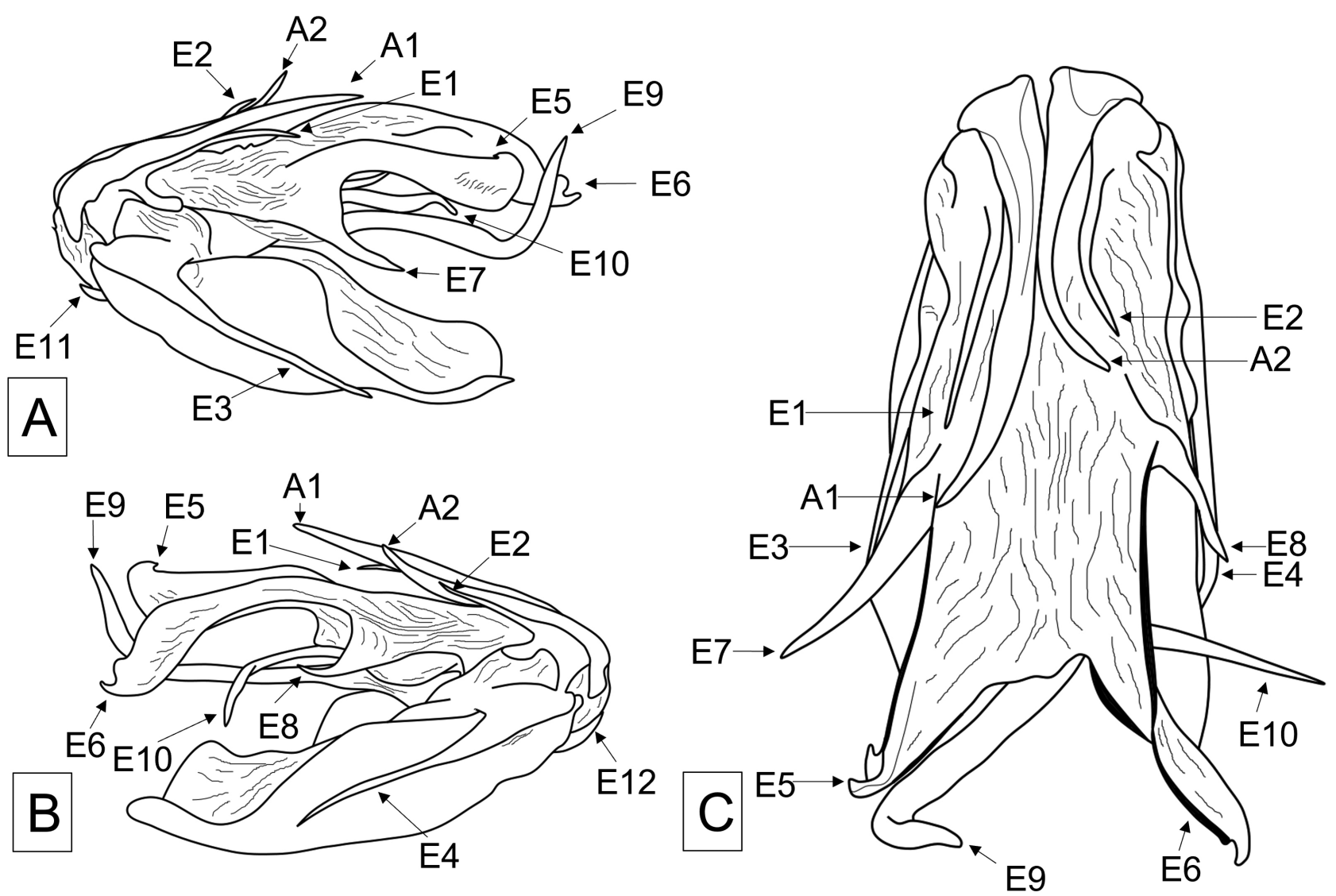

FIGURE 6. Line art for the aedeagus of Oropuna halo sp. n.; (A) right lateral view, (B) left lateral view, and (C) dorsal view, $\mathrm{E}=$ endosoma structures, $\mathrm{A}=$ aedeagal structures.

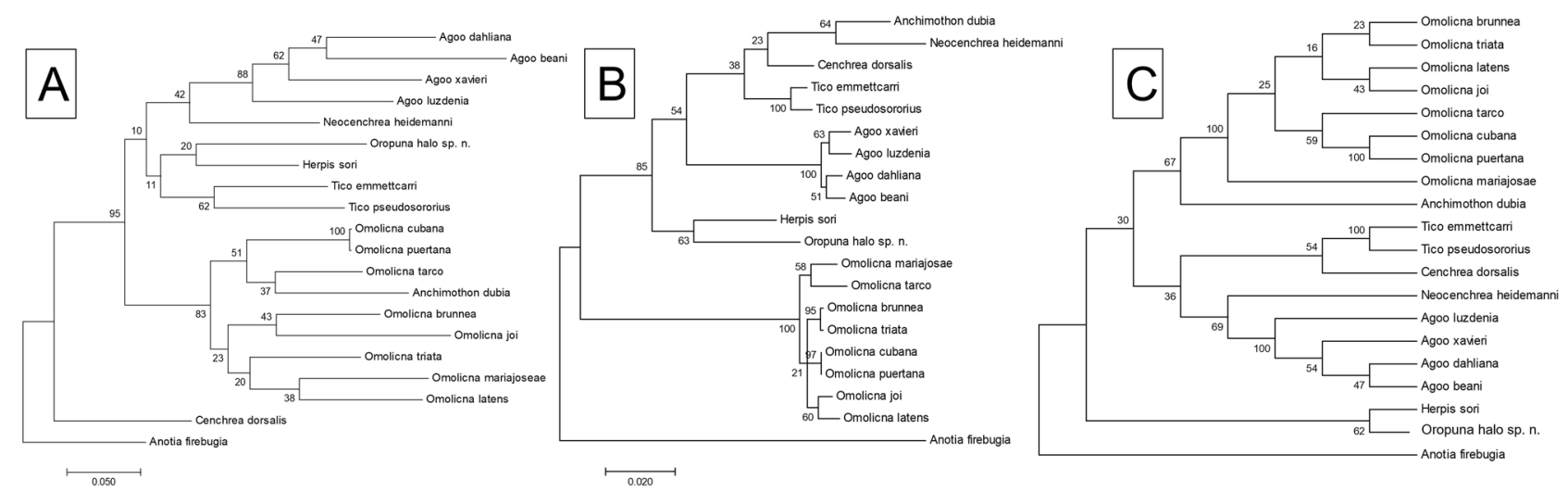

FIGURE 7. Maximum Likelihood phylogenetic trees (1,000 replicates) for currently available cenchreine planthoppers with Anotia firebugia as outgroup; (A) COI, (B) 18S, and (C) bootstrap consensus tree for concatenated COI and 18S data. 


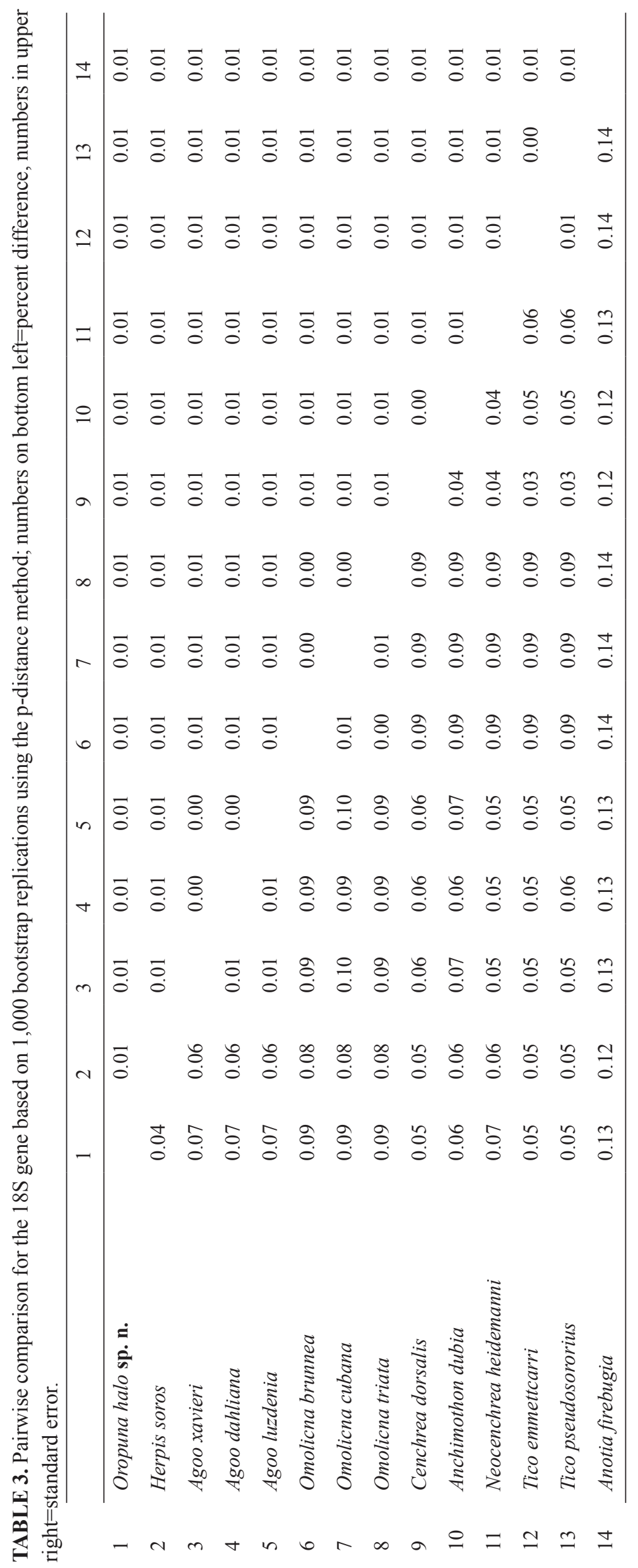




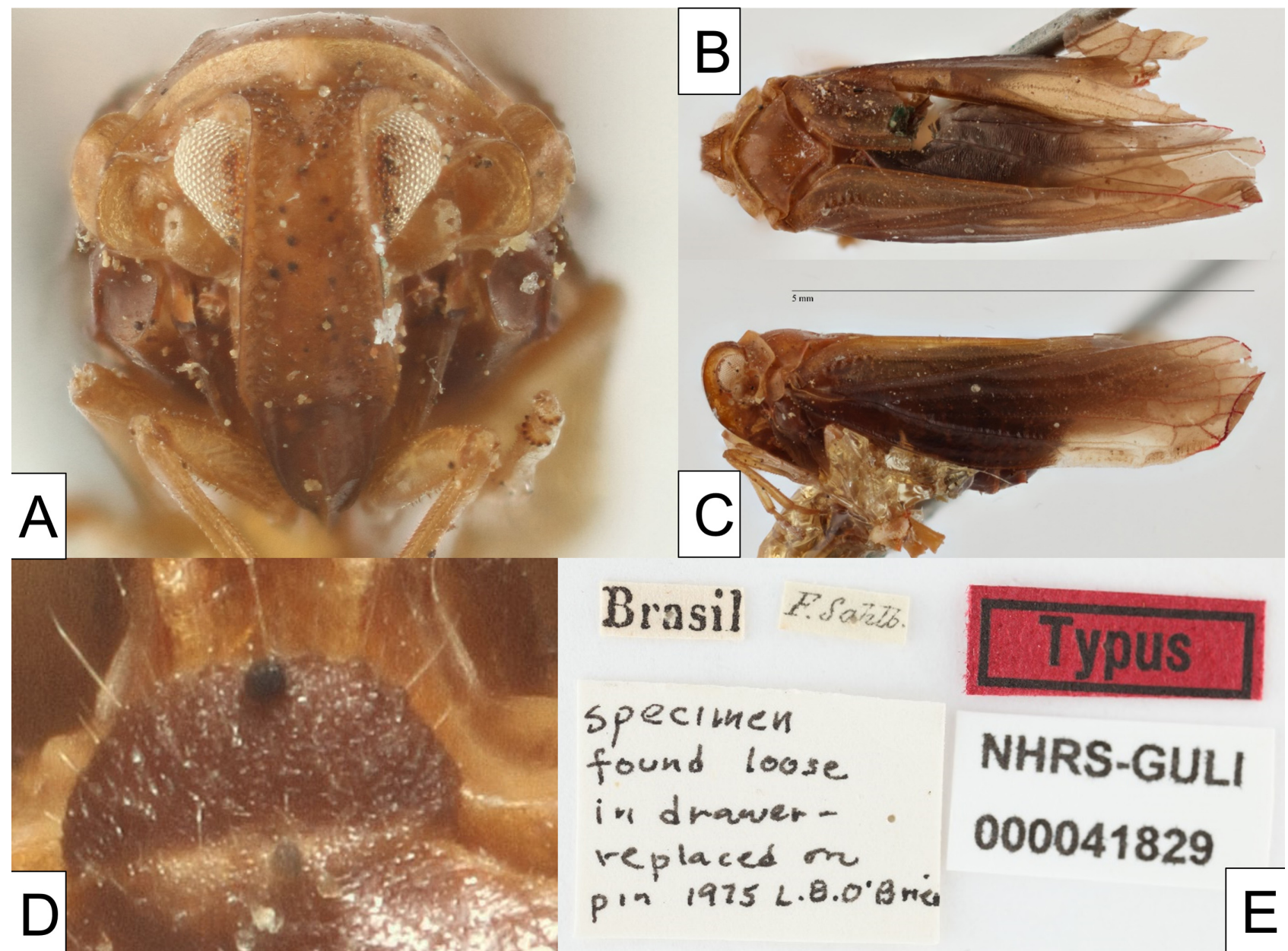

FIGURE 8. Holotype of Phaciocephalus orba (now Oropuna orba); (A) frontal view of head, (B) dorsal view of body, (C) lateral view of body, (D) female pregenital plate, and (E) labels.

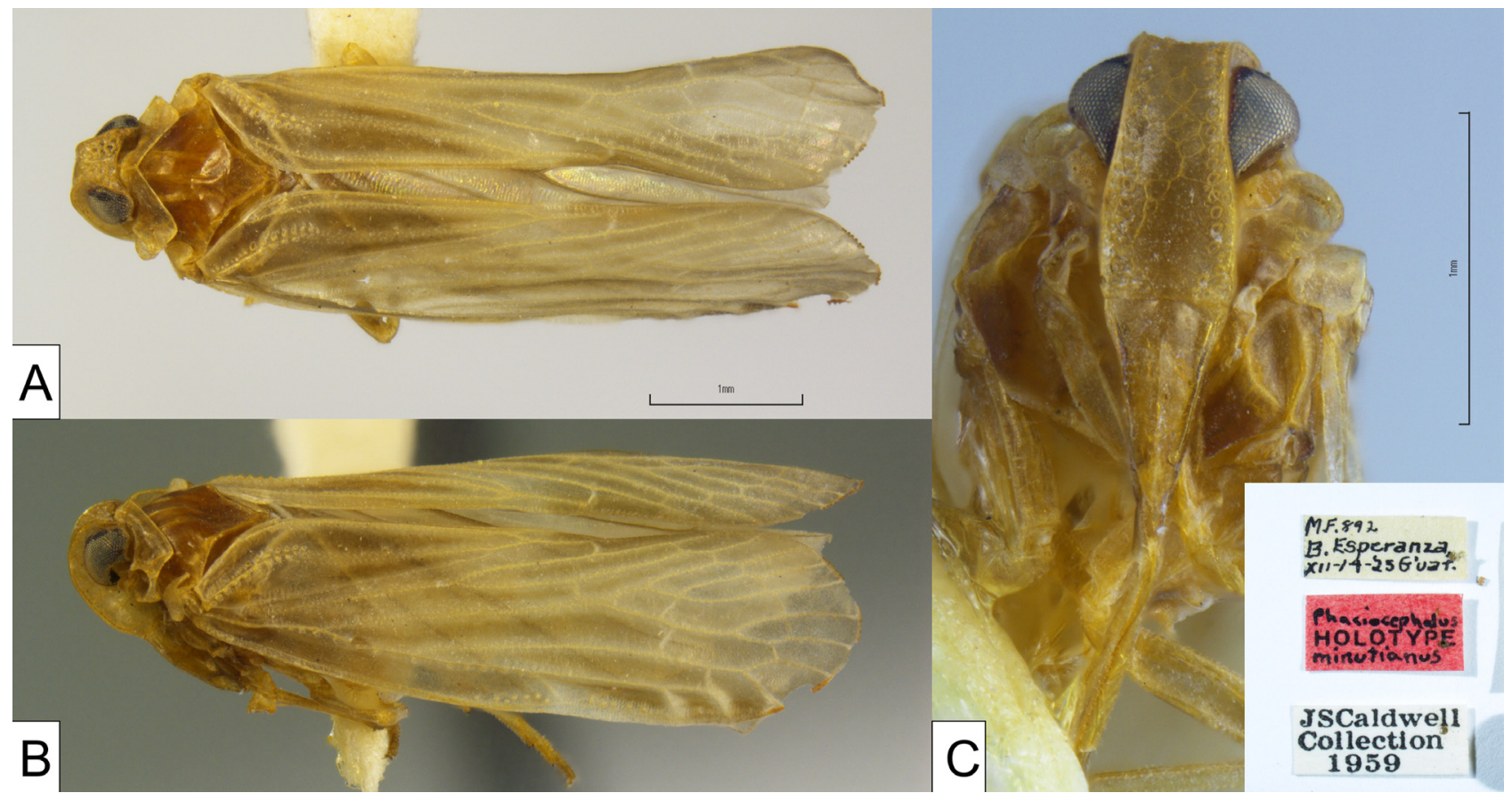

FIGURE 9. Holotype of Oropuna minutiana; (A) dorsal view, (B) lateral view and (C) frontal view of head. 


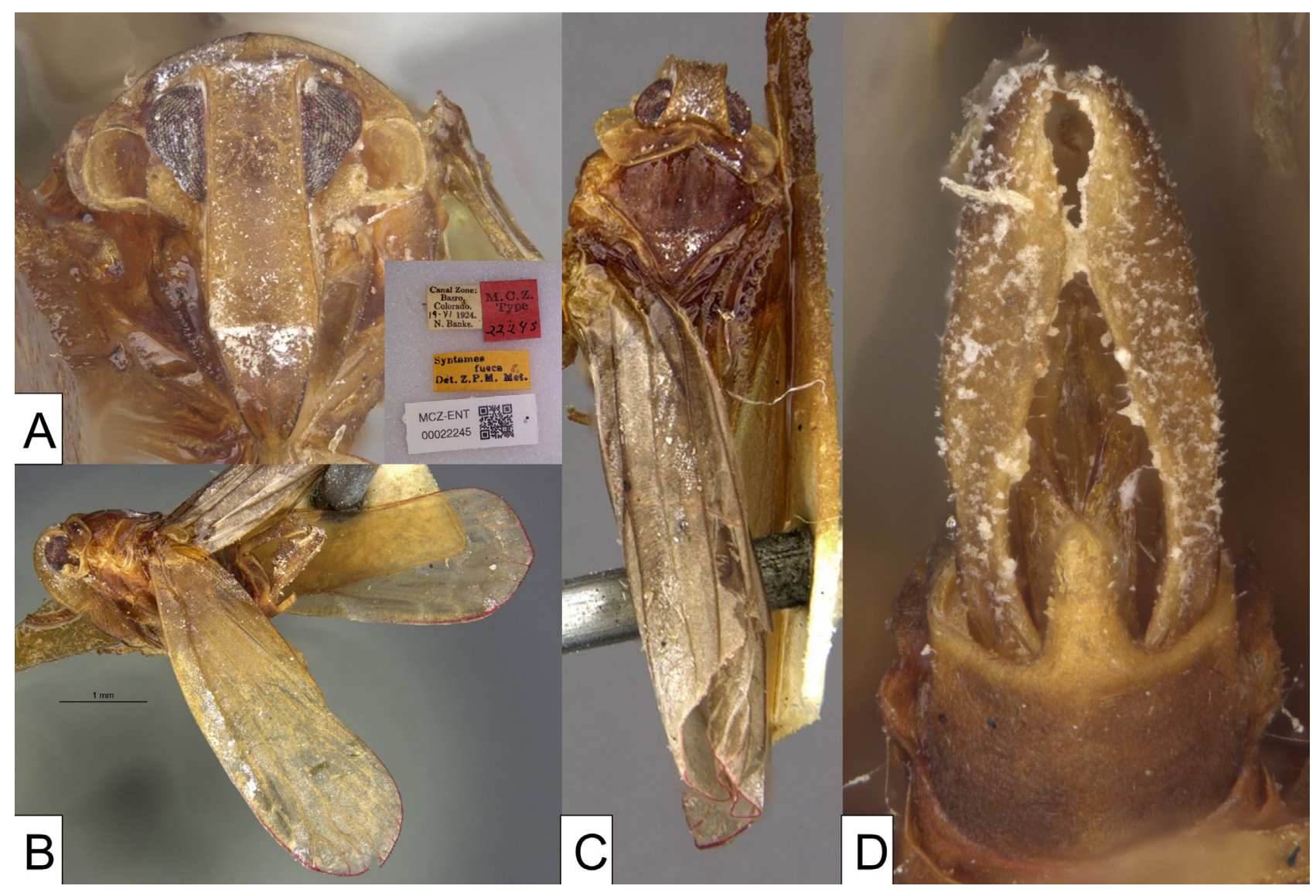

FIGURE 10. Holotype of Oropuna fusca; (A) head frontal view, (B) lateral view, (C) dorsal view and (D) ventral view of male terminalia (Harvard University, Cambridge MA; CPresident and Fellows of Harvard College, used by permission).

\section{Discussion}

The discovery of a species of Oropuna associated with palms indicates that about half of the new World Cenchreini have palm associates, viz. Agoo (Bahder et al. 2019), Herpis (Bahder et al. in review), Omolicna (Wilson et al. 2014), Tico (Bahder et al. 2020) and Oropuna (this work). The remaining New World cenchreine genera (Anchimothon Fennah, Cenanges Fennah, Cenchrea Westwood, Contigucephalus Caldwell, Neocenchrea Metcalf, and Persis Stål) have not yet been encountered directly associated with palms. We exclude Phaciocephalus Kirkaldy in this list because we believe the genus to be entirely Old World (See Bahder et al. 2021).

The new sequence data from Oropuna helps provide insight into the phylogeny of the Cenchreini. The concatenated COI and $18 \mathrm{~S}$ data indicate that Herpis + Oropuna represent a clade that is sister to the remaining Cenchreini. The presence of Herpis near the base of the tree might be expected as the absence of a median carina of the frons is derived in derbids (Emeljanov 1996, Emeljanov \& Shcherbakov 2020). Possibly, within the Cenchreini, the more derived taxa possess a more narrowed frons (e.g., the concave disc of frons and vertex). The phylogenetic relationships among the Cenchreini will require additional molecular data to stabilize the tree backbone, additional taxon sampling, and possibly additional outgroups - such as Cedochrusa Emeljanov or Cedochrea Emeljanov, within the Cedochreini, reputed to be closely related to the Cenchreini (Emeljanov 1996, Emeljanov \& Shcherbakov 2020). Also, the question of the relationships between New World and Old World Cenchreini remains to be addressed.

Based on currently recognized morphological characters that appear consistent for Oropuna, the movement of other taxa into Oropuna has brought the genus to four species; O. halo sp. n., O. minutiana, O. orba, and O. fusca. In future survey efforts, fresh male specimens of $O$. minutiana, $O$. orba, and $O$. serrata will be sought to further establish the genetic variability of the genus and test phylogenetic trends discussed in this study. 


\section{Acknowledgements}

The authors are grateful to the Organization of Tropical Studies and La Selva Biological Stations for supporting our efforts. The authors are grateful to Luz Bahder for translating the abstract into Spanish. Funding for this research was provided University of Florida - Institute of Food and Agricultural Sciences and Emerging Pathogens Institute for providing seed grant funding to support survey work in Costa Rica. We are very grateful to James Zahniser of the Smithsonian Institution for photos of the type specimen of Phaciocephalus minutianus, to Gunvi Lindberg from the Swedish Museum of Natural History for photos ot specimens from the Stål collection, and to The Museum of Comparative Zoology-Harvard Museum for making photographs of type specimens available online, and particularly to Crystal Maier at MCZ for providing an additional view of the type of Syntames fusca (images of Syntames fusca OPresident and Fellows of Harvard College, Harvard University, Cambridge MA, used by permission).

\section{References}

Bahder, B.W., Bartlett, C.R., Barrantes, E.A.B, Echavarria, M.A.Z., Humphries, A.R., Helmick, E.E., Ascunce, M.S. \& Goss, E.M. (2019) A new species of Omolicna (Hemiptera: Auchenorrhyncha: Fulgoroidea: Derbidae) from coconut palm in Costa Rica and new country records for Omolicna brunnea and Omolicna triata. Zootaxa, 4577 (3), 501-514. http://dx.doi. org/10.11646/zootaxa.4577.3.5

Bahder, B.W., Echavarria, M.A.Z., Barrantes, E.A.B., Helmick, E.E. \& Bartlett, C.R. (2021a) A new genus and two new species of planthopper in the tribe Cenchreini (Hemiptera: Auchenorrhyncha: Derbidae) from lowland tropical rainforest in Costa Rica. Zootaxa, 4908 (3), 369-392. https://doi.org/10.11646/zootaxa.4908.3.3

Bahder, B.W., Echavarria, M.A.Z., Barrantes, E.A.B., Helmick, E.E. \& Bartlett, C.R. (2021b) A new species of planthopper in genus Herpis (Hemiptera: Derbidae) from lowland tropical rainforest in Costa Rica. Zootaxa, 5032 (1), $121-135$. https://doi.org/10.11646/zootaxa.5032.1.7

Bartlett, C.R., O’Brien, L.B. \& Wilson, S.W. (2014) A review of the planthoppers (Hemiptera: Fulgoroidea) of the United States. Memoirs of the American Entomological Society, 50, 1-287.

Bourgoin, T. (1988) A new interpretation of the homologies of the Hemiptera male genitalia illustrated by the Tettigometridae (Hemiptera, Fulgoromorpha). In: Vidano, C. \& Arzone, A. (Eds.), Proceedings of the 6th Auchenorrhyncha Meeting, Turin, Italy, 7-11 September 1987. Consiglio Nazionale delle Ricerche, IPRA, Rome, pp. 113-120.

Bourgoin, T., Wang, R.R., Asche, M., Hoch, H., Soulier-Perkins, A., Stroinski, A., Yap, S. \& Szwedo, J. (2015) From micropterism to hyperpterism: recognition strategy and standardized homology-driven terminology of the forewing venation patterns in planthoppers (Hemiptera: Fulgoromorpha). Zoomorphology, 134 (1), 63-77. https://doi.org/10.1007/s00435-014-0243-6

Bourgoin, T. \& Huang, J. (1990) Morphologie comparée des genitalia mâles des Trypetimorphini et remarques phylogénétiques (Hemiptera: Fulgoromorpha: Tropiduchidae). Annales de la Société Entomologique de France, Nouvelle Serie, 26, $555-564$.

Caldwell, J.S. (1944) The tribe Cenchreini with special references to the Cenchrea complex (Homoptera: Derbidae). Bulletin of the Brooklyn Entomological Society, 39, 99-110.

Emeljanov, A.F. (1996) On the system and phylogeny of the family Derbidae (Homoptera, Cicadina). Entomological Review, 75 (2), 70-100. [English translation of Entomologicheskoe Obozrenie, 73 (4), 783-811 (1994) from Russian]

Emeljanov, A.F. \& Shcherbakov, D. (2020) The first Mesozoic Derbidae (Homoptera: Fulgoroidea) from Cretaceous Burmese amber. Russian Entomological Journal, 29 (3), 237-246. https://doi.org/10.15298/rusentj.29.3.02

Fennah, R.G. (1952) On the generic classification of Derbidae (Homoptera: Fulgoroidea) with descriptions of new Neotropical species. Transactions of the Royal Entomological Society of London, 103 (4), 109-170. https://doi.org/10.1111/j.1365-2311.1952.tb01063.x

Folmer, O., Black, M., Hoeh, W., Lutz, R. \& Vrijenhoek, R. (1994) DNA primers for amplification of mitochondrial cytochrome c oxidase subunit I from diverse metazoan invertebrates. Molecular Marine Biology and Biotechnology, 3 (5), $294-299$.

Kumar, S., Stecher, G. \& Tamura, K. (2016) MEGA7: Molecular Evolutionary Genetics Analysis version 7.0 for bigger datasets. Molecular Biology and Evolution, 33, 1870-1874. https://doi.org/10.1093/molbev/msw054

Metcalf, Z.P. (1938) The Fulgorina of Barro Colorado and other parts of Panama. Bulletin of the Museum of Comparative Zoology at Harvard College, 83 (5), 277-423.

Muir, F.A.G. (1913) On some new species of leafhoppers. Part II. Derbidae. Bulletin of the Hawaiian Sugar Planters'Association Experiment Station. Division of Entomology. Honolulu, 12, 28-92.

O’Brien, L.B. (1982) Two Neotropical derbid genera with observations on wing rolling (Fulgoroidea: Homoptera). Florida Entomologist, 65 (3), 306-321. 
https://doi.org/10.2307/3494303

Simon, C., Frati, F., Beckenbach, A., Crespi, B., Liu, H. \& Flook, P. (1994) Evolution, weighting, and phylogenetic utility of mitochondrial gene sequences and a compilation of conserved polymerase chain reaction primers. Annals of the Entomological Society of America, 87 (6), 651-701.

Spinola, M. (1839) Essai sur les Folgorelles, sous-tribu des Cicadaires, ordre des Rhyngotes. Annales de la Société Entomologique de France, 8, 133-337.

Wilson, S.W., Halbert, S. \& Bextine, B. (2014) Potential planthopper vectors of palm phytoplasma in Florida with description of a new species of the genus Omolicna (Hemiptera: Fulgoroidea). Florida Entomologist, 97 (1), 90-97. https://doi.org/10.1653/024.097.0112 